\title{
Perceptions of Dairy Farmers Regarding Self-made and Branded Feed in Punjab
}

\author{
Paramveer Singh Sallan, Parminder Singh*, Rajesh Kasrija and S. K. Kansal \\ Department of Veterinary and Animal Husbandry Extension Education, Guru Angad Dev \\ Veterinary and Animal Sciences University, Ludhiana, Indira \\ *Corresponding author
}

\begin{abstract}
A B S T R A C T
The present study was conducted on randomly selected 240 dairy farmers from Punjab contacted at various Kissan melas, Trainings, KVKs and seminars. 129 dairy farmers who were preparing self-made feed were selected as final respondents. The farmers were asked to rank reasons for likings of self-made feed and disliking of branded feed from $1^{\text {st }}$ rank to $8^{\text {th }}$ rank according to Garret's ranking technique on pre-selected reasons, which were compiled after scrutinizing relevant literature, consulting subject matter specialist and progressive farmers. 'Performance of dairy animals', 'Quality issue' and 'Costly feed' were reported to be reasons at $1^{\text {st }}, 2^{\text {nd }}$ and $3^{\text {rd }}$ rank respectively for not buying branded feed. Performance', 'Choice of ingredients' and 'milk production' were reported to be reasons at $1^{\text {st }}, 2^{\text {nd }}$ and $3^{\text {rd }}$ rank respectively for preparing self made feed. The commercial feed miller should consider these reasons, which were according to farmers' point of view for enhancing their market potential and to increase acceptability of branded feed by dairy farmers.
\end{abstract}

\section{Keywords}

Branded, Dairy,

Farmer, Feed,

Punjab, Self-made

Article Info

Accepted:

17 October 2020

Available Online:

10 November 2020

\section{Introduction}

Present-day high-producing dairy animals are the result of years of genetic improvement programmes. Dairy animals require nutrients for maintenance, growth, foetus development and milk production. Concentrates, important feed constituents are main sources of energy and protein, low in fiber, high in dry matter content and contain minerals that cannot be met from forage alone. In dairy farming, 60$70 \%$ expenditure was reported to be on concentrates. The poor concentrate feed (inadequate in both quality and quantity) is a major constraint in efforts to improve the productivity of dairy animals. Dairy farmers are either providing self-made concentrate feed or are dependent on branded/market feed. The feed industry has attempted to encourage the dairy farmers to feed branded concentrate and thus preventing farmers from making concentrate at their farms. However, the branded feed was introduced to enable dairy farmers to use higher technology levels, which may not be available to individuals in the farm. Branded feed will also help farmers to focus more on herd management issues instead of spending time on purchasing raw 
materials, mineral supplements and other components (Abdollahi et al., 2013). The various advantages with self-made feed were increasing farm efficiency by using on-farm by-products, reducing the cost of production where homemade rations are cheaper than branded feed. However, disadvantages with self-made feed were difficulty in maintaining quality control and balancing the ration because some ingredients may not be available, difficult to mix homogenously, especially for the ingredients used in small amounts, as mixing is done manually (Kitalyi et al., 2020). In Punjab, study regarding perception of dairy farmers regarding reasons for preferring branded feed or self made feed is not there.

\section{Materials and Methods}

The present study was conducted on randomly selected 240 dairy farmers of Punjab. The farmers were asked about preference of feed either self made or market/commercial feed. Out of 240 dairy farmers, $129(53.75 \%)$ were reported to be preferring self-made feed. These final respondents $(n=129)$ preparing self made feed were interviewed personally with the help of interview schedule. The interview schedule consisted of eight reasons for not buying branded feed and eight reasons for preferring self made feed.

These reasons were compiled after consultation with subject matter expert, relevant literature and after discussion with progressive dairy farmers. The dairy farmers were asked to rank these reasons in to rank order $1^{\text {st }}$ to $8^{\text {th }}$ according to quantum of effect on their dairy animals and on dairy farming. Garrett's Ranking technique (Garret and Woodworth, 1969) was used to evaluate these reasons given by dairy farmers. The orders of merit given by the dairy farmers were converted in to rank. The outcomes of such ranking have been converted into score value by following Garrett (1981) method, with the help of the following formula:

$$
\text { Per cent position }=\frac{100(\mathrm{Rij}-0.5)}{\mathrm{Nj}}
$$

Where Rij = Rank given for the ith variable by jth respondents

$\mathrm{Nj}=$ Number of variable ranked by $\mathrm{jth}$ respondents

With the help of Garrett's ranking conversion table 1, the estimated percent position is converted into Garret value. For individual rank order of individual reason, the Garret's score is calculated by multiplying number of dairy farmer falling under particular rank category with Garret value. Then for each rank, the scores of dairy farmers were added and then total value of scores and average values of score is calculated. The reason having highest average value is considered to be the most important reason cited by dairy farmer.

\section{Results and Discussion}

Table 2 represents the ranking order of dairy farmers of Punjab for not buying branded feed. For $1^{\text {st }}$ reason i.e. 'Costly feed', 29 dairy farmers placed it on $1^{\text {st }}$ rank and 39 dairy farmers placed it on $5^{\text {th }}$ rank, while for $6^{\text {th }}, 7^{\text {th }}$ and $8^{\text {th }}$ rank none of the farmer have given preferences. For 'Quality issue' reason, 29 dairy farmers placed it on $1^{\text {st }}$ rank.

Table 3 explains the calculation of Garrett's value and final ranking of reasons for not buying branded feed. 'Performance', 'Quality issue' and 'Costly feed' were reported to be at Ist, $2^{\text {nd }}$ and $3^{\text {rd }}$ rank respectively. It means that dairy farmers of Punjab are more concerned with performance of dairy animals after feeding the branded feed. The Quality issue of branded feed was also highlighted by dairy 
farmers, indicating the existence of low performance and spurious quality branded feed in the market. So, all branded feeds are not resulting in good performance of dairy animals and some may have quality issue with them. The 'Availability' reason was placed by farmers at last i.e. $8^{\text {th }}$ rank (Figure 1), indicating that branded feed is easily available for the farmers. It suggests that commercial feed companies are making arrangements for easy availability of branded feed to the dairy farmers. Sometimes, the commercial feed companies are providing incentives, giving advertisement, providing facility for home delivery of branded feed for easy availability at doorstep of farmer. However, John and Manoj (2013) reported that price, convenience, availability and quality are the major factors influencing the purchase decision of farmers for branded feed in Kerala. The branded/commercial feed companies should plan marketing strategies according to the preferences of farmers. John and Manoj (2014) also observed that meticulously planned and carefully designed marketing strategies are vital for sustained business growth and profitability of cattle feed manufacturers.

Table.1 Garrett value for each per cent position from Garret ranking conversion table

\begin{tabular}{|c|l|c|c|}
\hline Rank & $\mathbf{1 0 0}\left(\mathbf{R}_{\mathbf{i j}} \mathbf{- 0 . 5}\right) / \mathbf{N}_{\mathbf{j}}$ & Percent Position & Garret Value \\
\hline $\mathbf{1}$ & $100(1-0.5) / 8$ & 6.25 & 80 \\
\hline $\mathbf{2}$ & $100(2-0.5) / 8$ & 18.75 & 67 \\
\hline $\mathbf{3}$ & $100(3-0.5) / 8$ & 31.25 & 60 \\
\hline $\mathbf{4}$ & $100(4-0.5) / 8$ & 43.75 & 53 \\
\hline $\mathbf{5}$ & $100(5-0.5) / 8$ & 56.25 & 47 \\
\hline $\mathbf{6}$ & $100(6-0.5) / 8$ & 68.75 & 40 \\
\hline $\mathbf{7}$ & $100(7-0.5) / 8$ & 81.25 & 32 \\
\hline $\mathbf{8}$ & $100(8-0.5) / 8$ & 93.75 & 20 \\
\hline
\end{tabular}

Table.2 Ranking order of dairy farmers of Punjab $(n=129)$ for reasons for not buying branded feed in Garret's ranking technique

\begin{tabular}{|l|c|c|c|c|c|c|c|c|}
\hline \multirow{2}{*}{ Attributes } & \multicolumn{9}{|c|}{ Rank order } \\
\cline { 2 - 11 } & $\mathbf{1 s t}$ & 2nd & 3rd & $\mathbf{4}^{\text {th }}$ & $\mathbf{5 t h}$ & $\mathbf{6 t h}$ & 7th & 8th \\
\hline Costly feed & 29 & 0 & 31 & 30 & 39 & 0 & 0 & 0 \\
\hline Quality issue & 29 & 0 & 29 & 40 & 31 & 0 & 0 & 0 \\
\hline Availability & 0 & 0 & 0 & 0 & 37 & 0 & 29 & 63 \\
\hline Performance & 39 & 58 & 0 & 0 & 0 & 0 & 32 & 0 \\
\hline Fat or gravity & 0 & 0 & 0 & 0 & 57 & 72 & 0 & 0 \\
\hline Repeatability & 0 & 0 & 28 & 32 & 0 & 0 & 40 & 29 \\
\hline Milk production & 32 & 0 & 39 & 0 & 0 & 39 & 7 & 12 \\
\hline Conception & 0 & 72 & 0 & 29 & 0 & 0 & 28 & 0 \\
\hline
\end{tabular}


Table.3 Calculation of Garret value and ranking of dairy farmers $(\mathrm{n}=129)$ for not buying branded feed

\begin{tabular}{|c|c|c|c|c|c|c|c|c|c|c|c|}
\hline \multirow[t]{2}{*}{ Attributes } & \multicolumn{8}{|c|}{ Rank order } & \multirow{2}{*}{$\begin{array}{l}\text { Total } \\
\text { score }\end{array}$} & \multirow{2}{*}{$\begin{array}{l}\text { Mean } \\
\text { Score }\end{array}$} & \multirow[t]{2}{*}{ Rank } \\
\hline & 1st & 2nd & 3rd & 4th & 5th & 6th & 7th & 8th & & & \\
\hline Costly feed & 2320 & 0 & 1860 & 1590 & 1833 & 0 & 0 & 0 & 7603 & 58.94 & III \\
\hline Quality issue & 2320 & 0 & 1740 & 2120 & 1457 & 0 & 0 & 0 & 7637 & 59.20 & II \\
\hline Availability & 0 & 0 & 0 & 0 & 1739 & 0 & 928 & 1260 & 3927 & 30.44 & VIII \\
\hline Performance & 3120 & 3886 & 0 & 0 & 0 & 0 & 1024 & 0 & 8030 & 62.25 & I \\
\hline Fat or gravity & 0 & 0 & 0 & 0 & 2679 & 2880 & 0 & 0 & 5559 & 43.09 & VI \\
\hline Repeatability & 0 & 0 & 1680 & 1696 & 0 & 0 & 1280 & 580 & 5236 & 40.58 & VII \\
\hline Milk production & 2560 & 0 & 2340 & 0 & 0 & 1560 & 224 & 240 & 6924 & 57.73 & IV \\
\hline Conception & 0 & 4824 & 0 & 1537 & 0 & 0 & 896 & 0 & 7257 & 56.26 & $\mathrm{~V}$ \\
\hline
\end{tabular}

Table.4 Ranking order of dairy farmers of Punjab $(n=129)$ for reasons for preparing self made feed in Garret's ranking technique

\begin{tabular}{|l|c|c|c|c|c|c|c|c|}
\hline \multirow{2}{*}{ Attributes } & \multicolumn{9}{|c|}{ Rank order } \\
\cline { 2 - 10 } & $\mathbf{1 s t}$ & $\mathbf{2 n d}$ & $\mathbf{3 r d}$ & $\mathbf{4}^{\text {th }}$ & $\mathbf{5 t h}$ & $\mathbf{6 t h}$ & 7th & 8th \\
\hline In frontof eyes & 57 & 0 & 0 & 0 & 0 & 32 & 0 & 40 \\
\hline Choice of ingredients & 0 & 98 & 0 & 0 & 31 & 0 & 0 & 0 \\
\hline Cheaper & 39 & 0 & 0 & 0 & 0 & 58 & 0 & 32 \\
\hline Performance & 32 & 0 & 68 & 29 & 0 & 0 & 0 & 0 \\
\hline Fat or gravity & 0 & 0 & 28 & 0 & 0 & 0 & 101 & 0 \\
\hline Repeatability & 0 & 0 & 0 & 72 & 0 & 0 & 0 & 57 \\
\hline Milk production & 0 & 32 & 0 & 30 & 67 & 0 & 0 & 0 \\
\hline Conception & 0 & 0 & 31 & 0 & 29 & 40 & 29 & 0 \\
\hline
\end{tabular}

Table.5 Calculation of Garret value and ranking of dairy farmers $(n=129)$ for preparing self made feed

\begin{tabular}{|c|c|c|c|c|c|c|c|c|c|c|c|}
\hline \multirow[t]{2}{*}{ Attributes } & \multicolumn{8}{|c|}{ Rank order } & \multirow{2}{*}{$\begin{array}{l}\text { Total } \\
\text { score }\end{array}$} & \multirow{2}{*}{$\begin{array}{l}\text { Mean } \\
\text { Score }\end{array}$} & \multirow[t]{2}{*}{ Rank } \\
\hline & 1st & 2nd & 3rd & 4th & 5th & 6th & 7th & 8th & & & \\
\hline In front of eyes & 4560 & 0 & 0 & 0 & 0 & 1280 & 0 & 800 & 6640 & 51.47 & IV \\
\hline $\begin{array}{l}\text { Choice Of } \\
\text { Ingredients }\end{array}$ & 0 & 6566 & 0 & 0 & 1457 & 0 & 0 & 0 & 8023 & 62.19 & II \\
\hline Cheaper & 3120 & 0 & 0 & 0 & 0 & 2320 & 0 & 640 & 6080 & 47.13 & V \\
\hline Performance & 2560 & 0 & 4080 & 1537 & 0 & 0 & 0 & 0 & 8177 & 63.39 & I \\
\hline Fat or gravity & 0 & 0 & 1680 & 0 & 0 & 0 & 3232 & 0 & 4912 & 38.08 & VIII \\
\hline Repeatability & 0 & 0 & 0 & 3816 & 0 & 0 & 0 & 1140 & 4956 & 38.42 & VII \\
\hline Milk production & 0 & 2144 & 0 & 1590 & 3149 & 0 & 0 & 0 & 6883 & 53.36 & III \\
\hline Conception & 0 & 0 & 1860 & 0 & 1363 & 1600 & 928 & 0 & 5751 & 44.58 & VI \\
\hline
\end{tabular}


Fig.1 Reasons for not buying branded feed by dairy farmers of Punjab ( $n=129)$

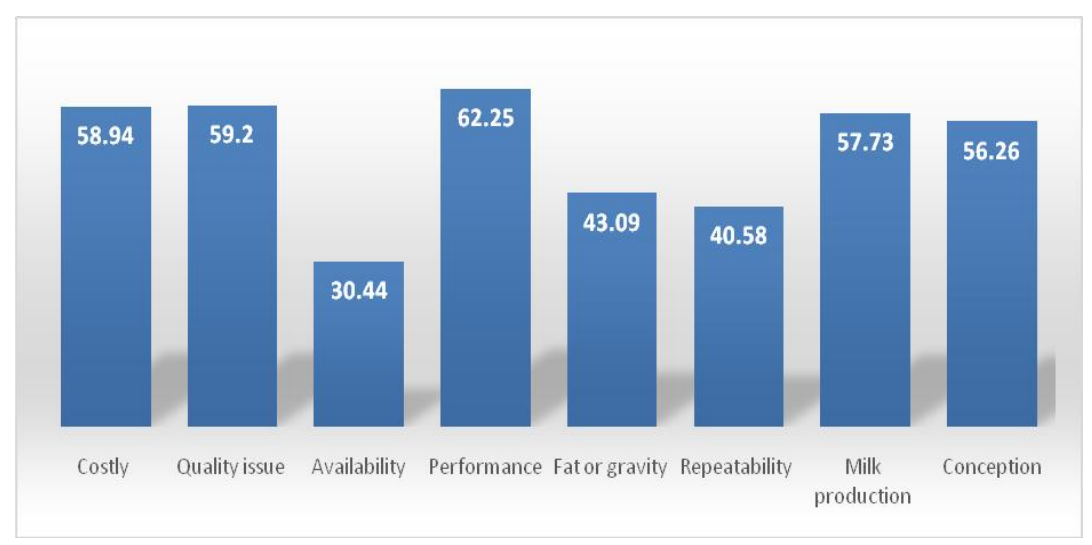

Fig.2 Reasons for preparing self made feed by dairy farmers of Punjab (n=129)

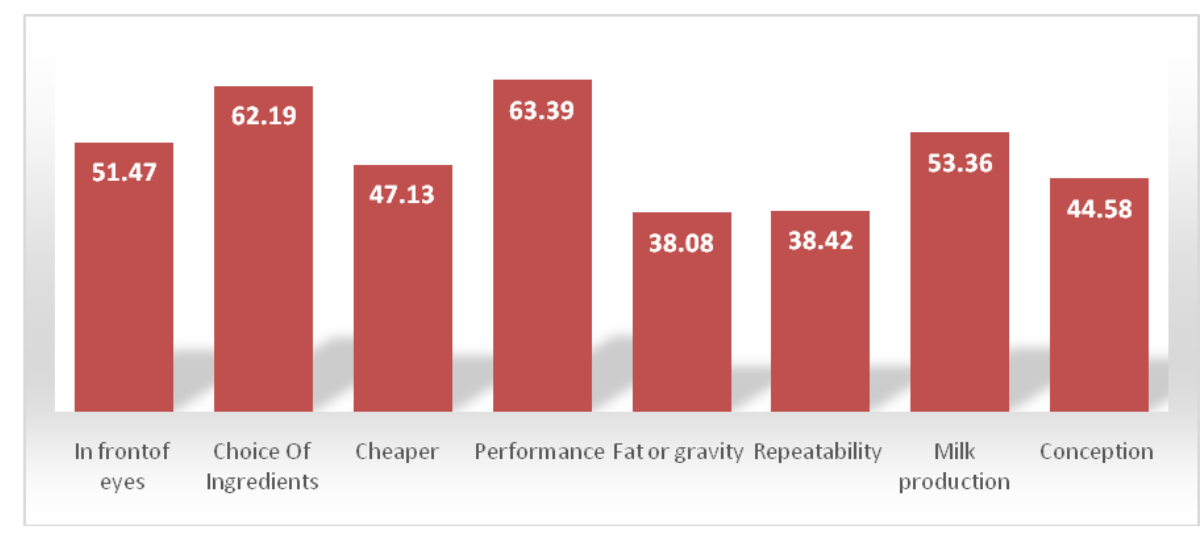

Table 4 represents the ranking order of dairy farmers of Punjab for reasons for preferences of preparation of self made feed. For reason 'In front of eyes', 57 dairy farmers placed it on $1^{\text {st }}$ rank, while 80 dairy farmers placed it on $8^{\text {th }}$ rank. For reason 'Conception', 31 dairy farmers placed it on $3^{\text {rd }}$ rank, while 29 dairy farmers placed it on $7^{\text {th }}$ rank.

Table 5 explains the calculation of Garrett's value and final ranking of reasons for preparing self made feed. 'Performance', 'Choice of ingredients' and 'milk production' were reported to be at $1^{\text {st }}, 2^{\text {nd }}$ and $3^{\text {rd }}$ rank respectively. It suggests that performance of dairy animal is of utmost concern for the dairy farmer for preparing self made/homemade feed. The self made feed might be giving good performance, resulting in more faith of the farmers. So, the branded feed companies should concentrate on performance of dairy animals, while formulating animal feed. Varmudy V (2012) also has observed that India has enough opportunities to meet the new market demands, but there needs to be an improvement in the health and productivity of farm animals. 'Choice of ingredient' was also a major reason perceived by dairy farmers for preparation of self made feed. It indicates that by making self made feed, the dairy farmer is able to incorporate easily available, cheap and good quality ingredients in to animal feed. Fat or specific gravity was placed at last i.e. $8^{\text {th }}$ rank (Figure 2). This indicates that dairy farmers were less concerned about fat or specific gravity. 


\section{References}

Abdollahi, M.R., Ravindran, V., Svihus, B. 2013. Pelleting of broiler diets: An overview with emphasis on pellet quality and nutritional value. Animal Feed Science and Technology, 179: 123.

Garrett, H.E. 1981. Statistics in Psychology and Education published by Vakils, Feffer and Simons Ltd., Mumbai.

Garrett, H.E. and Woodworth, R.S. 1969.Statistics in psychology and education. Vakils, Feffer and Simons Pvt. Ltd., Bombay, pp: 329.

John, M. P. and Manoj, P. K. 2013. Marketing Strategies for Cattle Feed Products in Kerala: an Empirical Study International Journal of Scientific Research, 12(2):9-12.
John, M. P. and Manoj, P. K. 2014. Prospects of cattle feed industry in India and strategies for utilizing the market potential: a study in kerala with a focus on factors influencing buyer behavior. International Journal of Business and General Management, 3(3): 1-12.

Kitalyi, A., Lukuyu, B., Kirui, J. and Kabirizi, J. 2020. Mixing and feeding homemade dairy concentrates EADD (East Africa Dairy development) leaflet no. 6 retrieved from https://cgspace.cgiar.org/bitstream/han dle/10568/12522/MixingDairyConcen trates.pdf? sequence $=2 \&$ is Allowed $=y$

Varmudy, V. 2012. Animal feed and fodder plagued by chronic shortages Facts for You, 32(8): 15-18.

\section{How to cite this article:}

Paramveer Singh Sallan, Parminder Singh, Rajesh Kasrija and Kansal, S. K. 2020. Perceptions of Dairy Farmers Regarding Self-made and Branded Feed in Punjab. Int.J.Curr.Microbiol.App.Sci. 9(11): 2462-2467. doi: https://doi.org/10.20546/ijcmas.2020.911.297 